\title{
THE DYNAMICS OF HOLY POWER AS REFLECTED IN NARRATIVE STRUCTURE IN THE LIVES OF ST MARTIN AND ST ANTHONY
}

\author{
Claire Fanger
}

Sulpicius Severus, in his Dialogues, makes an emphatic claim for the superiority of St Martin to all the holy men of the East. After a discussion of the wondrous deeds of some unnamed eastern holy men, Sulpicius declares that Martin's powers were all the more impressive because he was able to maintain his sanctity despite his contact with the world. Says Sulpicius:

Illi enim ab omni impedimento liberi, coelo tantum atque angelis testibus, plane admirabilia docentur operari : iste in medio coetu et conversatione populorum, inter clericos dissidentes, inter episcopos saevientes, cum fere quotidianis scandalis hinc atque inde premeretur, inexpugnabili tamen adversus omnia virtute fundatus stetit, et tanta operatus est, quanta ne illi quidem quos a te audivimus esse in eremo vel fuisse, fecerunt. ${ }^{1}$

[For [the eastern holy men], free from every impediment, with only heaven and the angels as witnesses, clearly were shown how to perform wonders; [but Martin], in the middle of crowds and commerce with people, among dissenting clerics, among enraged bishops, with almost daily scandals oppressing him on this side and that, nevertheless stood against everything, firmly fixed in invincible power, and performed feats so great that not even those of whom you have told us, who are or were in the desert, have done such things.] 
Sulpicius is unequivocal in his assertion that Martin's holiness - and, more important, the power of that holiness - ought to be seen as enhanced, rather than diminished, by the relative worldliness of his life.

In this and other ways Sulpicius works to set Martin apart from the eastern holy men. Yet despite his attempt, both in the Dialogues and the Vita Martini, to delineate Martin's virtus as being in a class by itself, Sulpicius also incorporates in his depiction of Martin many of the traditional attributes by which holy men are characterized in the eastern vitae. For example, as Clare Stancliffe points out, Sulpicius continues to insist on the extreme asceticism of Martin's life even after his episcopal consecration, and connects this asceticism directly with his power to perform miracles. ${ }^{2}$ Certainly such deference is only to be expected; for if Sulpicius wanted to show forth Martin as the qualified competitor of the eastern holy men, he had to show that Martin could compete on their terms. In a sense, Sulpicius wants to have his cake and eat it too; like the eastern saints, Martin must obtain his holiness, and concomitant power, from his asceticism; yet his power, unlike theirs, must be seen to gain a mysterious increase from the fact that he lived a more worldly life. It is not hard to see an element of the paradoxical in Sulpicius' claim: if Anthony could be accused of making the desert a city, Martin, by living up to wilderness standards of asceticism in closer contact with the world, might equally be accused of making the city into his own private desert. Like Anthony, Martin was assaulted by demons and prevailed; unlike Anthony, Martin prevailed as well in a life among men. And, if we accept the terms of Sulpicius' judgment, it was the latter victory that was the more significant.

Peter Brown, in his article "Eastern and Western Christendom in Late Antiquity," sets out some general distinctions between the relationships of Eastern and Western Christianity to their respective holy men and to the relics in which their holy power was preserved after they had died. The terms of his distinctions echo those of Sulpicius when he defines the holiness of St Martin as against the holy men of the East. In essence, Brown argues that the holy in the West had a more direct influence on local social and political power structures. The eastern holy man lived apart from society; "he gained his powers from retiring to the desert, to the antithesis of human life, where Christ had been served by the angels." 3 The holy, therefore, tended to manifest itself by its discontinuity with the human and with normal human expectations; it "was at its most holy when least connected with that conflict of human interests which it was constantly called upon to palliate." In the West, Brown observes, 
".he holy . . could be defined as it was in the East, in terms of a stark discontinuity between the human and the non-human .... And yet this discontinuous holy is deeply inserted into human society . . . . [Its] blessing is thought of as the intrusion into human life of those dead men and women who had persevered in clear roles within the human community rather than the desert. ${ }^{5}$

Whether or not this type of distinction between West and East would have been consciously made by western hagiographers in the fourth century (Brown, emphasizing a slightly later period, takes the majority of his illustrative examples from the writings of Gregory of Tours), it is certain that Martin's clear role in the human community was a matter to which Sulpicius gave deliberate emphasis in his presentation of the saint.

There are other aspects of the Vita Martini which are interesting to consider in the light of Brown's ideas about the relationship between society and the holy in East and West. Brown observes that "in the West, the precise locus of the supernatural power associated with the holy was fixed with increasing precision." 6 He elaborates on this statement by explaining that, in the West, a relic does not merely "enhance the status of a church or a locality, giving its favours indiscriminately to all connected with the site . . . Rather, the contact with the holy is used to mark out unambiguously those individual members of the community who enjoyed a permanent status different from the rest." 7 Relics might confirm or deny worldly authority, or behave in ways which would directly influence those who had responsibility for administration of the community. This could only happen, however, if the power of the holy was confined to a certain location; it must be alloted to the charge of certain individuals and must not be allowed to proliferate indiscriminately (as it seemed to do in the East). In the West, the localization of divine power in and around those objects that had been associated with the saint is integrally tied to the increasing practicality of their function.

Sulpicius' presentation of Martin in the Vita reveals several indications of a strong concern to depict manifestations of the holy as precisely localized phenomena, not merely on the level of social interaction or authority but also on a more concrete, material, and spatial level. If we compare the recorded deeds of Martin with those of Anthony, certain differences at once become apparent, both in the concerns of the saints and in their methods of operation. Martin is unlike Anthony in his commitment to the destruction of pagan temples and their replacement with churches or monasteries (for we are told that it was his custom to build a church or monastery wherever 
he destroyed a pagan temple). ${ }^{8}$ Peculiar to Martin also was his miraculous unmasking of the grave of the false martyr; having proved that a location reverenced by local villagers as the tomb of a martyr was in fact a bandit's grave, he set about destroying the shrine that had been built there by former bishops ( $V M$ XI). The miracles connected with these doings had immediate consequences in the social sphere, in increasing the size of the community of true believers and extending the authority of the Church. And they also show how intimately power in the community is connected with location: Martin's prime technique for converting large numbers of people at the same time was to identify and destroy (generally with miraculous help) the architectural space or landscape in which they worshipped as heathens. His worry over the authenticity of the martyr's tomb shows a similar concern with locality; in this instance he undertook to guide people away from wrong worship by guiding them away from the location in which such worship took place. In his preoccupation with sacred ground Martin shows a very different type of motivation from that of Anthony, whose concerns over land and territory are nearly all connected with his desire to get away from other people.

Another feature which notably distinguishes Martin's miraculous deeds - specifically those involving healing, exorcism, or raising the dead - from similar deeds performed by Anthony, is the importance of touch in effecting the miraculous cure. For Martin, the process of cure nearly always involves physical contact with the afflicted person or body part, whether he simply touches the person or whether the touch involves the application of some oil or salve. Where cures are effected in Martin's absence, they are likely to involve touching the invalid with some object associated with Martin, such as a letter. Anthony's cures, by contrast, are nearly always described as being effected either by the power of his prayers or by a more nebulous power operating through Anthony whose actual mechanism is left undescribed. Touch (save in the case of one exorcism) ${ }^{9}$ is not mentioned; there is no application of salves or oils, and no recognizable medical procedures are involved in any of his cures. Anthony's actual presence at the scene of the healing is, in many cases, not even necessary. True, Sulpicius does ascribe to Martin some cures effected in the saint's absence and by the power of his prayers and fasting alone. These, however, comprise a minority of the total number of his cures, and for whatever reason account of all of them appears in the Dialogues; in the Vita there is no cure described which does not involve the touch of Martin or the touch of some object associated with him. 
Th ? importance accorded Martin's physical presence and touch in effecting healings and exorcisms indicates a concept of holy power tending to manifest itself within local boundaries. The saint's virtus emanates from a set of specific points (the saint's body and those objects which have been in contact with the saint's body) and operates most effectively within a close range of one of these points. In the Vita Antonii the saint's virtus is presented as operating in a very different way. Anthony's physical location does not have nearly as direct a relationship to the manifestations of his power as does Martin's. In fact, Anthony's more characteristic miracles often involve causing things to happen at some remove from his person or seeing or knowing about things that have happened far away.

From this outline it may be seen that the hagiographers' representations of the two saints involve concepts of holy power which show radical differences in their mechanism. Some of these differences are readily accounted for as manifestations of Brown's paradigm of eastern and western Christianity; yet it is patent that there is more to be said. Brown's treatment of the subject is sweeping, and he strives for no more than a general articulation of main points. More specific questions hang fire: Do the saints, as represented by their hagiographers, seem to understand the operation of their own power? If so, how is this understanding represented? What kind of emphasis does Sulpicius put on the fact that Martin must have physical contact with his patients in order to cure them? And if Anthony's cures seldom require physical contact, is this fact emphasized by his biographers? If so, how are we informed that he is in fact the operative link between God and the patient? Is the structure of the relationship between the human and the divine reflected in the structure of these narratives? Such questions about the operations of holy power may best be answered by in-depth examination of the biographies of the men who wielded it.

To attempt a complete and detailed analysis of the two vitae would be a project beyond the scope of the present paper. However, to give some idea of what such an analysis might reveal, it is my intention here to make a detailed comparison of two sets of stories - the first involving exorcism, the second involving healing - from the lives of Martin and Anthony. The stories are drawn from Evagrius Latin version of Athanasius' Life of Anthony ${ }^{10}$ and from Sulpicius' Vita Martini (though I make occasional reference to the Dialogues). My primary interest here is to see what the narrative structure of the stories reveals about the operation of holy power in each saint. Through a close reading of specific miracle stories, using methods of literary analysis, it should be possible to articulate in more specific terms how each saint 
functioned as a focus of divine power. It is hoped that such an examination will aid in refining and clarifying Brown's paradigm.

Let us begin by considering a set of exorcisms.

Martin

Per idem tempus, in eodem oppido, ingressus patris familias cuiusdam domum, in limine ipso restitit, dicens horribile in atrio domus daemonium se uidere. Cui cum ut discederet imperaret, cocum patris familias qui in interiore parte aedium morabatur, arripuit, saeuire dentibus miser coepit, et obuios quosque laniare. Commota domus, familia turbata, populus in fugam uersus. Martinus se furenti obiecit, ac primum stare ei imperat. Sed cum dentibus fremeret hiantique ore morsum minaretur, digitos ei Martinus in os intulit: si habes, inquit, aliquid potestatis, hos devora. Tum vero, ac si candens ferrum faucibus accepisset, longe reductis dentibus digitos beati viri vitabat attingere; et cum fugere de obsesso corpore poenis et cruciatibus cogeretur, nec tamen exire ei per os liceret, foed a relinquens vestigia fluxu ventris egestus est. ( $V M$ XVII)

[In the same time period, in the same town, upon entering the house of a certain householder, he stopped right at the threshold saying that he saw a horrible demon in the front room of the house. When he ordered it to depart it took possession of the householder's cook, who was lingering in the interior part of the building, and the wretched man began to do violence with his teeth and to lacerate those who got in his way. The house was in an uproar, the servants were all upset, the people turned in flight. Martin threw himself in front of the madman and first ordered him to be still; but when he gnashed his teeth and threatened, with gaping mouth, to bite, Martin stuck his fingers into his mouth. "If you have any power," he said, "eat these." And then, as if he had received a glowing poker in his jaws, he drew his teeth far back as he avoided touching the fingers of the blessed man. And when [the demon] was forced by its pains and torments to flee the possessed body - and yet it was not permitted to exit through the mouth - it was discharged in a stream from the bowels leaving a trail of filth.]

\section{Anthony}

Alius quoque ad eum vir, inter suos nobilis, daemoniosus adducitur, tanta oppressus insania, ut non sciret se esse apud Antonium, necnon et corporis sui superflua comederet. Quamobrem rogatus senex ab his qui eum adduxerant ut pro illo Dominum oraret, intantum juvenis miseriae condoluit, ut tota nocte pervigilans cum eo, adversus patientis insaniam laboraret. Sed cum jam lucesceret, et obsessus, impetu in Antonium facto, vehementer eum impulisset, irasci coeperunt qui eum adduxerant, cur seni fecisset injuriam. Quibus Antonius ait: Nolite alienam culpam juveni misero ascribere: furor iste obsidentis est, non obsessi. Idcirco autem in hanc proruit dolens hostis audaciam, quia Dominus ad aridam regionem ire eum jussit; et expulsi Satanae indicium iste adversum me impetus fuit. Nulla post verba mora, adolescens recepto 
sen $: u$, et gratias agens Deo, et locum ubi esset, agnovit, et toto Antonium complexans deosculatus est affectu. (VAXXXVI)

[And another man was brought to him, a noble among his own people, who was demonically possessed by a madness so great that he did not know that he was with Anthony, nor that he was eating his own bodily discharge. For this reason, when those who had brought him asked the old man to pray to the Lord on his behalf, he so much pitied the wretchedness of the youth that he stayed awake with him the entire night toiling against the insanity of his patient. But presently when day broke, and the possessed man, having made a rush at Anthony, gave him a violent push, those who had brought him there began to get angry because he might have done an injury to the old man. Anthony said to them: "Do not ascribe to the wretched youth a sin not his own. That rage comes from the possessor, not the possessed. Moreover the sorrowful enemy has fallen into a fit of pique because the Lord has commanded him to go into the dry desert - and that push against me was the sign of Satan's expulsion." Shortly after these words the youth, in his right mind and thanking God, both recognized the place where he was and, embracing Anthony, kissed him with complete fondness.]

I have placed these two stories in apposition not only because they both involve exorcising demons of similar behaviour but also because both involve the saint's physical contact with the patient. In Anthony's case the contact is not intentional, being no more than an accidental manifestation of the departing demon. And yet this physical contact serves a specific purpose in the story, since it allows Anthony to demonstrate that his understanding of the situation is more complete than that of the surrounding onlookers. Anthony has stayed up all night with his patient, praying and watching with him, and presumably it is simply the fact of Anthony's attention to the situation that has been the principal force in compelling the demon to leave. The way in which this force operates is not readily intelligible, however; for Anthony's mere presence seems to have no immediate effect on the possessed youth at all, and even the eventual physical contact between himself and the young man is not presented as the cause of the demon's expulsion but rather as a result of it. Indeed, the actual act of exorcism seems to take place, not in the ordinary world inhabited by ourselves and the bystanders, but above it, in the otherworld of supernatural powers - - a place to which only Anthony has access.

The point of the story, then, is not merely to demonstrate that Anthony was able to expel the demon, but also to show how he was able to explain the demon's behaviour from his intimate knowledge of happenings in the spiritual realm. The family of the possessed youth naively supposes that the sudden attack on Anthony was willed by the young man; Anthony knows 
that the actions of the young man are not the result of his own will, but are caused by another. Further, he knows that the push was the demon's final act of aggression, and that the youth will now recover from his indisposition. Anthony's action in praying for the possessed youth must thus be seen as an attempt to make contact with the supernatural world - to find out what is really happening - as much as an attempt to control the demon's exits and entrances. When he reveals the cause of the young man's attack on his person, he explains it as a manifestation of the demon's annoyance at being commanded by God to go into the desert. How would he know this if he himself had not overheard the Lord's command and observed the demon's response? What is marvellous is not merely that he has served as a conduit for God's power in healing the youth, but that he has apparently witnessed without mediation the confrontation between God and the demon, a confrontation which was visible to the rest only by signs and tokens.

The saint's knowledge of the otherworld is important in the Martinian story as well, but in a quite different way. Here, the story begins with Martin's witnessing of a demon that is invisible to other people. However, from the mere seeing of the demon which opens the story Martin goes on to get progressively closer to the evil spirit, finally making intentional physical contact with the possessed man, which directly causes the demon's expulsion. Sulpicius describes with some care the set of physical and spatial relationships which frame the events of the narrative. Entering a house, Martin pauses on the threshold (in limine) because he sees a demon in the front room (in atrio). He commands the demon to leave, whereupon it takes possession of the householder's cook, who was lingering further inside the building (in interiore parte aedium). Since the demon was presumably barred from leaving the house by the front door (in the same way that it was later barred from exiting the householder's cook by the mouth), we may extrapolate that the demon probably intended to exit the house by the back door and capriciously decided to grab a human victim on its way. Beyond the demon's progression from the front part of the house toward the back, we note that it has also receded to a further interiority: deterred by Martin's command from occupying the interior of the house it has withdrawn to the interior of one of the householder's servants. In a sort of cat and mouse game, Martin closes in on it. Having entered the house, he thrusts himself in front of the raving madman and orders him to be still. The demon, enraged by Martin's proximity, causes the possessed man to gnash his teeth still more and to threaten Martin with physical violence. Martin then realizes that verbal commands will not be enough, and, as he had followed the demon 
into the house, now follows it into the householder's servant by thrusting his fingers down the man's throat. The demon responds to Martin's touch as if to the pain of a white hot iron and quickly recedes from the possessed body by, as it were, the back door.

It was important for Sulpicius to emphasize that Martin had knowledge of the hostile demon (and thus, in some sense, of the events about to happen) prior to anyone else in the story. To this extent Martin resembles Anthony. However, the presentation of Martin's foreknowledge does not seem to be an end in itself; it is used to set up the narrative rather than to finish it off, and serves rather as a technique to build suspense than as a denouement. The story indeed seems to be designed to put us in suspense; our sense throughout is that Martin is in more danger than Anthony ever was, even though the threat of physical violence is present in both narratives.

One does not have to look far to find reasons for this. Note that Martin did not have to go out of his way to find the demon; he did not have to make a special effort to contact the supernatural world, nor did he seek out the demon in a deserted place or tomb. Rather, the demon seems to have sought Martin out; it has forsaken the otherworld to make an appearance on earth, in a place where it manifestly does not belong: the dwelling of a local householder. Small wonder, then, that Martin's job seems more dangerous than Anthony's: the desert, with its ghostly presences, its monsters and its demons, has begun to encroach upon the city. Martin, no longer a mere gobetween, has become more of a border guard, the protector of the boundary between that world and this. Hence Sulpicius' emphasis on boundaries, and hence also our sense of the danger Martin was in; he follows the demon into the house much as Beowulf follows Grendel into the mere. Sulpicius lays stress on enclosure, on proximity, on entrance and exit, so that we may comprehend sympathetically the risk that Martin took. We end up feeling that we have witnessed the actual process of the exorcism at much closer hand than we did in the case of Anthony. And so, in a sense, we have. For the act of exorcism in the story of Martin takes place very much in this world - the world of the innocent bystander and the world of the reader.

Let us look next at a set of healings.

\section{Martin}

Curationum vero tam potens in eo gratia erat, ut nullus fere ad eum aegrotus accesserit, qui non continuo receperit sanitatem. Quod vel ex consequenti liquebit exemplo. Treveris puella quaedam dira paralysis aegritudine tenebatur, ita ut iam per multum tempus nullo ad humanos usus corporis officio fungeretur: omni ex parte praemortua vix tenui spiritu palpitabat. Tristes ad solam funeris expectationem adstabant propinqui, cum subito ad 
civitatem illam Martinum venisse nuntiatur. Quod ubi puellae pater conperit, currit exanimis pro filia rogaturus. Et forte Martinus iam ecclesiam fuerat ingressus. Ibi, spectante populo multisque aliis praesentibus episcopis, eiulans senex genua eius amplectitur, dicens: filia mea moritur misero genere languoris, et, quod ipsa est morte crudelius, solo spiritu vivit, iam carne praemortua. Rogo ut eam adeas adque benedicas: confido enim quod per te reddenda sit sanitati. Qua ille voce confusus obstipuit, et refugit dicens hoc suae non esse virtutis, senem errare iudicio, non esse se dignum per quem Dominus signum virtutis ostenderet. Perstare vehementius flens pater et orare ut exanimem visitaret. Postremo, a circumstantibus episcopis ire conpulsus, descendit ad domum puellae. Ingens turba pro foribus, expectans quidnam Dei servus esset facturus. Ac primum, quae erant illius familiaria in istius modi rebus arma, solo prostratus oravit. Deinde, aegram intuens, dari sibi oleum postulat. Quod cum benedixisset, in os puellae vim sancti liquoris infundit, statimque vox reddita est. Tum paulatim singula contactu eius coeperunt membra vivescere, donec firmatis gressibus populo teste surrexit. (VM XVI)

[So powerful in him was the grace of healing that hardly any sick person came to him who did not immediately recover health, as the following example will make plain. A certain young girl of Treves was in the grip of a severe paralytic illness, so that for a long time now she had no use of the human functions of her body. Dead in every part, she barely trembled with the slightest breath [spirit] of life. Her sorrowing relations were standing by in the sole expectation of her death, when suddenly it was announced that Martin had come to the city. When the girl's father heard this, he ran breathless to ask [Martin's intervention] on behalf of his daughter. By chance Martin had just now entered the church; here, with the people looking on, and with many other bishops present, the old man, lamenting aloud, embraced his knees and said: "My daughter is dying with a wretched kind of sickness, and one that is more cruel than death itself; in breath [spirit] alone she lives, in flesh she is dead already. I ask that you go to her and bless her, for I believe that through you she may be restored to health." [Martin], confused by this speech, was dumbfounded and shrank back, saying that this was not in his powers, that the old man made an error in judgment, that he was not worthy that the Lord should show a sign of power through him. Weeping harder, the father insisted, and pleaded for Martin to visit the dying girl. Finally, compelled to leave by the surrounding bishops, he went down to the girl's house. There was a huge crowd before the doors awaiting whatever the servant of God was about to do. And first - this was a familiar armament of his in things of this kind - he prostrated himself on the ground and prayed. Next, looking at the sick girl, he asked that some oil be given to him. When he had blessed it, he poured the potency of the sanctified liquid into the girl's mouth, and immediately her voice returned. Then, bit by bit, each of her limbs began to revive by its contact, until, as the people attest, she rose up on steady feet.] 


\section{Anthony}

Virgo vero quaedam, quae de Busiris Tripolitanae regionis civitate ibidem erat, inauditis ac flebilibus morbis laborabat. Etenim narium purgamenta, oculorum lacrymae, aurium putridus humor in terram cadens confestim in vermes vertebantur. Augebat calamitatem corpus paralysi dissolutum, oculos quoque perversos contra naturam habens. Hanc parentes ejus deferentes, cum ad Antonium monachos ire didicissent; credentes in Domino, qui pertinacem sanguinis fluxum in Evangelio tactu fimbriae stare praeceperat rogaverunt ut miserabilem filiae comitatum susciperent. Illis renitentibus eam usque ad Antonium perducere, remansere parentes ejus foris cum filia debili apud beatum confessorem et monachum Paphnutium, qui effossis pro Christo oculis sub Maximiano persecutore, tali dehonestamento corporis plurimum gloriabatur. Pervenerunt igitur ad Antonium monachi. Cumque de morbo puellae referre disponerent, relationem eorum senis sermo praevenit; et omnem debilitatis et itineris usque ad sanctum Paphnutium causam, quasi ipse interfuisset, exposuit. Rogantibus autem eum monachis, ut parentibus cum filia permitteretur ingressus, non concessit, sed ait: Ite, et invenietis puellam, si non est mortua, curatam. Et adjecit: Nullus debet ad meam humilitatem venire, quia largitio curationum non est humanae miseriae, sed Jesu Christi misericordiae, qui ubique in se credentibus praestare consuevit auxilium. Quamobrem et illa, pro qua petitis, suis precibus liberata est; et cum ad Dominum orarem ego, mihi praescientia sanitatis ejus indulta est. Dixit, et verba ejus puellae incolumitas secuta est. Nam exeuntes foras ad beatum Paphnutium, et filiam sospitem, et parentes laetos repererunt. ( $V A X X X)$

[A certain young girl who was from the same city of Busiris in the region of Tripoli suffered with a set of bizarre and lamentable complaints. For the discharge from her nose, the tears from her eyes, and a stinking liquid that came out of her ears all turned into worms immediately upon falling to earth. It made matters worse that her body had slipped into paralysis with the eyes unnaturally crossed. Her parents, giving an account of her when they had learned that some monks were going to Anthony (and believing in the Lord, who, in the Gospel, had ordered a persistent issue of blood to stop with a touch of his hem), had asked them if they would receive the girl's unhappy retinue into their company. As they refused to bring her all the way to Anthony, the parents remained some distance away with the crippled girl, at the house of the blessed monk and confessor Paphnutius (who, having had his eyes gouged out for Christ under the persecutor Maximian, gloried much in this disfigurement of his body). The monks therefore went on to Anthony. And when they purposed to tell about the sickness of the girl, the old man's speech prevented them; and he described every important fact of the illness and of the journey all the way to holy Paphnutius, as if he himself had been among them. Moreover, when the monks asked him if the parents and their daughter might be permitted entry, he refused, but said: "Go, and you will find that if the girl is not dead she is cured." And he added: "People ought not to come to me, humble as I am, since the gift of healing belongs not to human misery, but to Jesus' mercy; He is accustomed to furnish help to those 
believing in him everywhere. For which reason the girl on whose behalf you petition is liberated by her own prayers. And since I have been praying to God, foreknowledge of her cure has been granted me." He spoke, and the girl's cure followed his words. For going out to the blessed Paphnutius, they found the girl healthy and her parents happy.]

In both stories we find the saints refusing to approach their patients; both claim to be unworthy of the faith placed in them by the petitioners; both deny that the power of healing belongs to them. In each narrative, however, the sequence of events sets up an entirely different context for interpretation of these statements. In the case of Anthony the disclaimer comes near the end of the story; also, it occurs after at least part of the miracle has been performed. Here, as with the exorcism discussed previously, the revealing of Anthony's superior knowledge is part of the point of the story; he has already impressed the monks (and presumably the reader) with a point by point account of the girl's illness and her journey. Anthony's denial of his own power forms part of a further disclosure on the nature of the spiritual events about to occur; he explains to the monks that cures come only from God, not men, and that hence the girl's own faith and prayers are directly responsible for her healing. He attributes his knowledge of this event to the fact that he has also been praying to God, but claims no further responsibility for the cure.

The reader must not, of course, be so complacent as to to take Anthony's denial of his own power at face value. It should first of all be noted that the pattern of the narrative is reflective of a certain type of Gospel miracle story, which culminates in Jesus' assertion that the patient's own faith has caused the healing. In the Gospel, these statements are coloured by Christ's typically parabolic way of speaking; they seem open ended and enigmatic, in part because even here Christ is involved in the verbal dissemination of spiritual truths which may be conveyed only in a veiled form, but in part also because no one present in fact doubts for a moment that it is Christ who is directly responsible for the cure. His assertion that the cure was not caused by him is thus something to be pondered and expounded, rather than accepted and forgotten. Anthony likewise propounds statements which have something of the quality of enigma; his denial of his healing powers must in this context be interpreted not merely as a direct assertion of his humility, but also as an indirect assertion of his divinity. Indeed, the parenthetic reference to the woman with the issue of blood in the third sentence seems designed to make the association of Anthony with Christ unavoidable; for this Gospel story is one which ends "Filia, fides tua salvam 
te fecit." ("Daughter, your faith has made you well," Matt. 9:22, cf. Luke $8: 48)$.

There is, however, one salient difference between the Gospel story and the story of St Anthony: the woman with the issue of blood is healed when she touches the hem of Christ's garment; the woman from the city of Busiris never gets anywhere near Anthony. In Luke's Gospel it is made abundantly clear that this act of touching was independently significant in the process of the cure, since Christ says immediately afterwards: "Tetigit me aliquis: nam ego novi virtutem de me exiisse." "Someone has touched me: for I know that power has gone out of me," 8:46). ${ }^{11}$ In this regard it may well be that the most significant thing about the Gospel reference in Anthony's miracle story is the fact that allusion to this healing touch has been suppressed. There is another indirect allusion to the woman with the issue of blood later on in the Vita Antonii (Cap. XLII), where we are told that the people "Ambiebant quoque saltem fimbriam vestimenti ejus attingere, multum sibi et tactum prodesse credentes." ("They also flocked about [Anthony] to touch at least the hem of his robe, believing that the touch would much benefit them.") We are not told whether any effect followed this touch (either in general or in any particular case), and are left to interpret for ourselves Evagrius' oddly ambiguous use of the word "credentes." It really ought to have a positive connotation in a story of this kind, impressing us with the strong faith of the people; yet its effect both here and in the healing story is to leave us wondering if the people involved were not in some degree merely credulous.

This effect is probably deliberate. Anthony is not Christ - or rather not quite. Christ lived here in the flesh only once; he is not here any more. Or rather he is here, but shows himself only through visions and signs and tokens, through enigmatic manifestations of his power. Anthony is and is not here in the same way that Christ is and is not here, and he poses a similar kind of riddle for his followers. The riddle, however, is now at one remove from its origin; it has become a bit more puzzling, a bit harder to answer. Anthony's deeds of power seem to require a good deal of explanation; they tend to be wrapped up in words and signs, in narrative of the unseen events surrounding odd occurences. Anthony himself is likewise a sign of power, and conversely it might be said that his power is the power of signs: it generates and transmits meaning, it is quite arbitrarily connected with his person, it operates at a distance. Christ's power might operate at a distance, but the theological implications of his physical, carnal presence were always important too; Anthony's carnal presence is consistently, significantly suppressed. 
Not so with Martin. As in the story of the exorcism, Martin's bodily presence is important: the cure does not occur until he has approached the girl, and his physical distance from the patient is always known. The girl's father finds Martin in the church, pleads with him to come, and finally leads him to her house. Martin begins by praying, then pours into her mouth some oil which he has consecrated and into which the divine power has passed. The girl promptly recovers the use of her limbs, "contactu eius" - at the touch of the holy liquid. ${ }^{12}$ This final sentence provides a brief but graphic sketch of the process which is supposed to be occurring inside the girl: her voice is restored immediately as the oil comes into contact with her vocal cords, and we can imagine its subsequent diffusion throughout her body, as it is more slowly absorbed into her system through the digestive tract. We are thus made witness to the actual process of the cure, and we are left in no doubt that the cure has occurred through Martin's direct agency.

Paradoxically, Martin's denial of the power of healing which the girl's father attributed to him earlier in the story serves only to emphasize the fact of his agency. The old man had said "confido quod per te reddenda sit sanitati." ("I believe that through you she may be restored to health.") Martin's denial of such power is express and specific: unlike Anthony, he does not merely assert that he is a mortal man and that the power of cures is denied mortal men in general; rather, he claims that "non esse se dignum per quem Dominus signum virtutis ostenderet." ("He was not worthy that the Lord should show a sign of power through him.") In this sentence, the mechanism of transmission of God's power is more clearly intelligible than it ever was in the story of Anthony. Its operation is made to appear similar to that of electricity; it moves through specific conduits and its transmission proves and enhances the worth of the person serving as conduit. Martin is not in doubt that a man may be significantly operative in transmission of God's power; he doubts only that he personally is worthy to be considered for the task. The circumstances of the story guide the reader in interpretation of this disclaimer: prior to the occurrence of any miraculous events, Martin denies his ability to perform miracles; at the urging of the bishops, he goes to the girl and performs the miraculous cure anyway. The reader is thus led to the conclusion that Martin was simply wrong; he had underestimated his own worth. God had, in fact, chosen him to be the focus, conduit, and storehouse of divine power.

Whereas in the case of Anthony the denial of power served as an enigmatic assertion both of the saint's humility and his divinity, in the case of Martin the denial of power serves as a straightforward assertion of humility. 
The denial is not made part of the miraculous events themselves; it is not to be read as seme or morpheme which makes part of the sign of power. The sign of power comes at a later point in the story, and contradicts the earlier words of Martin. The healing represents something new, the point at which signifier is momentarily contiguous with signified, the sudden juncture where divine power is manifested as power in a sign. Martin's virtus might be defined as the fact that such a contiguity is able to occur through him: the arbitrary, enigmatic, fallen nature of the sign, which is so carefully preserved in the story of Anthony, is miraculously controverted by Martin. Whereas through Anthony the operations of the heavenly and supernatural world are made visible in signs and tokens, through Martin, the heavens leap to earth.

We begin now to gain a clearer understanding of why Sulpicius Severus insisted so vehemently on the superiority of Martin's virtus over that of Anthony and other eastern holy men of the same style. Martin's power, located so firmly in the city, was able to be of far more use than Anthony's. This is true not merely because proximity made it easier for Martin to help people and not merely because Martin was able to maintain his holy power steadily in spite of the stress and strain of city life, but because it was a more useful kind of power to begin with. Its locus was certain; its effects were immediate; its action was visible. Martin brought the heavens down to earth and God into the house. His deeds of power, by momentarily stripping ambiguity and enigma from the sign, re-clothed the word in flesh.

In the introductory part of this paper I wrote somewhat facetiously of Martin making, by his ascetic practices, the city a desert. In fact, the desert appears to have entered the city before Martin ever got there. The city here must be taken to be synonymous with the sublunary world, with the territory that belongs or ought to belong to men; as a spiritual location, it is opposed both to the desert and to the heavens, when the proper relations exist between them. When the proper relations do not exist, when demons invade the world, then the heavens also must find an adit. In an age where Satan might appear anywhere - in a monastery wielding a bloody ox-horn or in the living room of the average householder - many people must have been grateful that God found such an adit in Martin.

But there is more to it than this. It was not merely that Martin's powers were necessary to the city, but that the city was necessary to Martin's powers. As Sulpicius hints, it made them greater than they otherwise might have been. In the narratives previously discussed, we have seen how careful Sulpicius is to give us a sense of Martin's location, and how location is used 
to build tension in the stories. Martin's power requires interiors, churches, houses, or crowded street corners, to be adequately showcased. The same stories could not have been told of someone who sat alone, having visions under the open sky. Under such conditions, it is barely possible to imagine how power as great as Martin's could manifest itself. Power like Martin's requires a definite location, and only in the world, in the city, do such definite locations exist; for only in the world does it matter where you are. In the desert, in the region of airy powers, one place is much like another for all practical purposes.

This is so true that it is difficult to tell whether Anthony's own proper sphere is the desert or heaven itself. It is certainly not the world; there is a way in which Anthony hardly seems to exist in the world at all. He appears always to be possessed of an intimate knowledge of events in the supernatural world. He often seems well informed about events in the natural world as well, but this knowledge also comes to him from a supernatural plane. The physical location of his person has little to do with the manifestations of his power, which seem to occur somewhat wantonly, now near at hand, now far away. If the model for Martin's transmission of power is electric, Anthony's might be described as telegraphic. And the metaphor is, for the moment, an apt one, considering the fact that Anthony is concerned as much with the transmission of meaning as the transmission of power.

This does not mean that he or his actions are always readily intelligible. They are not, but this is not his fault; the problem of intelligibility lies in the world, which is not really his territory. When God shows signs of power through Anthony, these manifestations partake more of the nature of signs as we know them. They are meant to be interpreted. This is not a denial of their miraculous nature, but rather a demonstration of it; for how could any manifestation of God among men be readily intelligible to a fallen world? Thus Anthony, so concerned with intelligibility, remains himself something of a walking enigma, a sort of flesh made word.

Centre for Medieval Studies/University of Toronto

NOTES

1 Dialogus I Cap. XXIV, following the edition in the Patrologia Latina, 20.183-202.

2 Clare Stancliffe, St Martin and his Hagiographer(Oxford 1983) 151-53.

3 Peter Brown, "Eastern and Western Christendom in Late Antiquity," in Society and the Holy in Late Antiquity (New York 1982) 181. 
4 Brown (at n. 3) 182.

5 Brown (at n. 3) 191-92.

6 Brown (at n. 3) 178.

7 Brown (at n. 3) 187-88.

8 Sulpicius Severus, Vita Martini, Cap. XIII, following the edition by Jacques Fontaine in Vie de Saint Martin, Sources Chrétiennes 133 (Paris 1967) I, 248-345. Chapter references will follow the citation in brackets from here on.

9 This occurs in Cap. XLIX when Anthony is involved in a dispute with some pagan philosophers; he exorcises some demons to prove the superiority of the Christian God. We are told that "cum vitale signum in sacro numero Trinitatis pressisset in frontibus, una cum expulsis daemonibus vana praesentium philosophorum confutata sapientia est." ("When he had pressed the living sign in the holy number of the Trinity on their foreheads, the vain wisdom of the philosophers present was silenced along with the expelled demons.") This is the only instance I can find in which Anthony deliberately touches his patients.

10 I have chosen to use Evagrius' Latin version of Athanasius since it was almost certainly the one which Sulpicius Severus would have known, and against which he would have been reacting in his depiction of Martin. Another valuable study might be undertaken comparing Athanasius' Greek with Evagrius' Latin version of the Vita Antoniz. For comparison the reader is referred to Athanasius' version in PG 26.835-976, and the translation by R.T. Meyer, The Life of St Anthony, Ancient Christian Writers 10 (Westminster, Maryland 1950). I follow the edition of Evagrius which appears in PL 73.125-94. Further chapter references will follow the citation in brackets.

11 In the book by J.M. Hull, Hellenistic Magic and the Synoptic Tradition, (London 1974), this incident is discussed (105-10) as evidence of magical thinking in the Gospels, particularly in Luke. Many of the more magical aspects of Christ's miracles seem well fitted for adaptation to the concerns of Martin, since Martin's miracles are often accomplished by touch; it is thus a bit surprising that Sulpicius does not make more frequent and specific allusions to Gospel precedents, or design his narratives in such a way as evoke particular Gospel stories. When he does do so, it is usually in a straightforward manner, without comment; in Dialogue III, for example, it is briefly mentioned that a woman suffering from an issue of blood was cured by touching Martin's garment, as in the Gospel story (Cap. IX). He offers no edifying exposition of this incident. Apparently the nature of the relationship between Martin and Christ did not seem particularly baffling or troublesome to Sulpicius; in the Vita Antonii, the nature of Anthony's relationship to Christ is consistently commented upon and might almost be called a major theme.

12 It might be possible to read this phrase as "at his touch," i.e., at the touch of Martin; however, it seems to me more likely that Sulpicius is talking about the touch of the oil. Sulpicius is everywhere careful to give a point by point account of Martin's actions; the saint's precise gestures are important, and it seems reasonable to assurne that if Martin's touch had been meant, there would have been no ambiguity. 
